\title{
Constitutional Court of the Republic of Indonesia: Does the Ultra Petita Principle Reflect the Truth of Law?
}

\author{
Bagus Hermanto $^{1}$, I Gede Yusa ${ }^{2}$, Nyoman Mas Aryani ${ }^{3}$ \\ ${ }^{1}$ Faculty of Law, UniversitasUdayana, Indonesia, E-mail: bagushermanto9840@ gmail.com \\ ${ }^{2}$ Faculty of Law, UniversitasUdayana, Indonesia,E-mail: E-mail: gedeyusa345@gmail.com \\ ${ }^{3}$ Faculty of Law, UniversitasUdayana, Indonesia, E-mail: E-mail: mas.aryani@gmail.com
}

\begin{tabular}{|c|c|}
\hline Article Info & Abstract \\
\hline $\begin{array}{l}\text { Keywords: } \\
\text { The decision of the Constitutional } \\
\text { Court, Truth of Law, Ultra Petita } \\
\text { How to cite: } \\
\text { Bagus Hermanto, I Gede Yusa, } \\
\text { Nyoman Mas Aryani, } \\
\text { "Constitutional Court of the } \\
\text { Republic of Indonesia: } \\
\text { Does the Ultra Petita Principle } \\
\text { Reflect the Truth of Law?," Fiat } \\
\text { Justisia: Jurnal Ilmu Hukum 14, } 3 \\
\text { (2020): 261-286. } \\
\text { DOI: } \\
\text { 10.25041/fiatjustisia.v14no3.1902 }\end{array}$ & $\begin{array}{l}\text { Constitutional Court is one of the conductors in } \\
\text { Indonesia's judicial power as regulated by Article } \\
24 \text { (2) and Article } 24 \text { C (1) through (6) of the } 1945 \\
\text { Constitution of the Republic of Indonesia, that } \\
\text { adjudicates at the first and last levels whose decision } \\
\text { is final including in the context of judicial review in } \\
\text { the Constitutional Court. The provisions of H.I.R. } \\
\text { and R.Bg. firmly reflect one of the principles in the } \\
\text { civil procedural law, namely ultra petita, that } \\
\text { represent judges prohibition from making decisions } \\
\text { beyond what is requested. However, the practice in } \\
\text { the Constitutional Court found several } \\
\text { Constitutional Court Decisions classified as ultra } \\
\text { petita decisions so that there is an academic step to } \\
\text { justify the existence of Constitutional Court ruling } \\
\text { that determine as ultra petita decisions. This study } \\
\text { aims to find the justification of the Constitutional } \\
\text { Court in deciding ultra petita through a } \\
\text { philosophical, theoretical and legal dogmatic } \\
\text { perspective. This study used a normative legal } \\
\text { method with the conceptual approach, case studies } \\
\text { approach, and legislation or statutory approach. } \\
\text { This study shows that based on characteristics of } \\
\text { cases under the authority of the Constitutional } \\
\text { Court, it cannot be said that the prohibition of ultra } \\
\text { petita can be applied to justice in the Constitutional } \\
\text { Court, both from a philosophical, theoretical, and } \\
\text { legal dogmatic based on several Constitutional } \\
\text { Court Decision. }\end{array}$ \\
\hline
\end{tabular}




\section{A. Introduction}

The judicial power shall be conducted inter alia by the Constitutional Court. ${ }^{1}$ Establishment of Constitutional Court is an implementation of constitutional supremacy framework. ${ }^{2}$ This is stipulated in Article 24 (2) and Article 24C (1)-(6) of the 1945 Indonesian Constitution, ${ }^{3}$ "even though the parliament still has power in the formation of laws, ${ }^{4}$ the validity of the law established by the parliament can be review for constitutionality through an institution that is authorized to conduct the constitutionality". 5 The constitutional examination in Court carries the vision that majority decisions are not always true because a law has been passed and is in effect by the state legislature. ${ }^{6}$ This vision does not mean that the law has certainly met the formal and material aspects of making laws and does not conflict with the1945 Indonesia Constitution provision. Majority of politicians' decision is not always constitutional truth.

In practice, the Constitutional Court in examining and adjudicating constitutional review cases always adheres to the judge's conviction in addition to the evidence in the framework of achieving substantive justice, so that in practice, the Constitutional Court often decides cases more than those requested. ${ }^{7}$ On the other hand, the provisions of Article 178 paragraph (2) and (3) Herzeine Indonesische Reglement (H.I.R.) and Article 189 paragraphs (2), and (3) (Rechtreglement Voor de Buitengewesten) R.Bg. firmly reflects one of the principles in the civil procedural law namely ultra petita, that judges are prohibited from making decisions beyond what is requested. ${ }^{8}$ However,

\footnotetext{
1 W.Wijayanti, "Eksistensi Undang-undang sebagai Produk Hukum dalam Pemenuhan Keadilan bagi Rakyat (Analisis Putusan Mahkamah Konstitusi Nomor 50/PUU-X/2012),' Jurnal Konstitusi 10, No. 1 (2013): 179-204, doi: https://doi.org/10.31078/jk\%25x.

${ }^{2}$ N. M. Aryani, \&B. Hermanto, "Gagasan Perluasan Lembaga Negara sebagai Pihak Pemohon dalam Sengketa Kewenangan antar Lembaga Negara di Mahkamah Konstitusi Republik Indonesia," Jurnal Legislasi Indonesia 16, No. 2 (2019):173-189.

${ }^{3}$ I Gede Yusa and Bagus Hermanto, et.al., Hukum Tata Negara Pasca Perubahan UUD NRI 1945, Cetakan Pertama, (Malang: Setara Press, 2016), 103-104.

4 D. J. Nardi, "Can NGOs Change the Constitution? Civil Society and the Indonesian Constitutional Court", Contemporary Southeast Asia 40, No. 2 (2018): 247-278, doi: 10.135.CSA.247-278.

${ }^{5}$ M.Safta, "Developments in the Constitutional Review: Constitutional Court between the Status of Negative Legislator and the Status of Positive Co-Legislator", Perspective of Business Law Journal 1, No. 1 (2012):1-20.

${ }^{6}$ L. W. Eddyono, "Independence of the Indonesian Constitutional Court in Norms and Practices", Constitutional Review 3, No. 1 (2017): 71-97, doi: https://doi.org/10.31078/consrev314.

${ }^{7}$ M. Mietzner, "Political Conflict Resolution and Democratic Consolidation in Indonesia: The Role of the Constitutional Court", Journal of East Asian Studies 10, No. 3 (2010): 397-424, doi: https://doi.org/10.1017/s1598240800003672, p. 417.

8 The Center for Research and Case Study of the Constitutional Court categorizes of the constitutional court of Indonesia from 2003 until 2013 into several models, inter alia: (1) legally null and void model; (2) conditionally constitutional model; (3) conditionally unconstitutional
} 
based on the characteristics of the case under the authority of the Constitutional Court, it cannot be said that the ultra petita prohibition can be applied to justice in the Constitutional Court, ${ }^{9}$ both from a philosophical, theoretical and legal dogmatic perspective. On the other hand, ultra petita decisions in procedural law and practice are commonly applied by the Constitutional Court in various countries. One of them, Article 45 of the South Korean Constitutional Court Law, ${ }^{10}$ which in essence states, the Constitutional Court decides whether or not a constitutional law or a provision of the law not only against the provisions petitioned.

The Constitutional Court also affirmed its attitude through several ultra petita Constitutional Court Decision in a constitutionality review case is absolute. ${ }^{11}$ However, it must be accompanied by boundaries that can be assessed from a philosophical, theoretical and dogmatic perspective.

This article looks explicitly for, examines and analyzes how the Constitutional Court Procedural Law regulates and recognize ultra petita decisions and how the truth of law and limitation of ultra petita decisions on the decisions of the Constitutional Court in philosophical, theoretical and dogmatic perspectives, as one of the references for law scientific progress, specifically the dynamics of the Constitutional Court Procedural Law.

The legal research method divided into normative legal research and empirical legal research. ${ }^{12}$ Based on this classification, this article is classified as normative legal research by focusing on norms problems with prescriptive disciplines. This article is based on preliminary research with collecting and analysing primary legal materials and secondary legal materials using library research ${ }^{13}$ to answer the legal problem. This study uses a statute or legislation approach, conceptual approach, the cases studies approaches based on a legal material analysis technique in the form of a snowball system. In the research

model; (4) limited constitutional model and (5) decision model which formulates new norms. See on A. Omara, "The Indonesian Constitutional Court and the Democratic Institutions in Judicial Review", Constitutional Review 3, No. 2 (2017): 189-207, doi: 10.31078/consrev323, p. 193.

${ }^{9}$ M. A. Safaat, A. E. Widiarto \& F. L. Suroso, "Pola Penafsiran Konstitusi dalam Putusan Mahkamah Konstitusi Periode 2003-2008 dan 2009-2013", Jurnal Konstitusi 14, No. 2 (2017): 234-261, doi: 10.31078/jk1421, pp. 241-242.

${ }^{10}$ M. Shapiro, "Role Constitutional Court and Problem in Field Constitutional Court", Indiana Journal of Global Legal Studies 20, No. 1(2013): 253-277, p. 253.

${ }^{11}$ The Constitutional Court of Indonesia, Model dan Implementasi Putusan Mahkamah Konstitusi dalam Pengujian Undang-Undang (Jakarta: Registrar's Office and Secretariat General of the Constitutional Court of the Republic of Indonesia, 2013), 25.

${ }^{12}$ D. L. Sonata, "Metode Penelitian Hukum Normatif dan Empiris: Karakteristik Khas dari Metode Meneliti Hukum”, Fiat Justisia: Jurnal Ilmu Hukum 8, No. 1 (2014): 15-35, DOI: https://doi.org/10.25041/fiatjustisia.v8no1.283, pp. 25-27.

${ }^{13}$ N. Choudhury, "Revisiting Critical Legal Pluralism: Normative Contestations in the Afghan Courtroom," Asian Journal of Law and Society 4, No. 1 (2017): 229-255, doi: 10.1017/als.2017.2, p. 231. 
process, analysis and construction of legal material have been collected and processed.

\section{B. Discussion}

\section{Judicial Review as Constitutional Court of Indonesia Authorities}

The term judicial review merged during Ancient Greece and before the 19th century. It developed after the United States Supreme Court decision in the case of Marbury vs Madison in 1803 when the court annulled the provisions of the Judiciary Act of 1789 because it was contrary to the United States Constitution. ${ }^{14}$ However, there are no provisions either that regulates an authority of the judicial review is given to the Supreme Court. This matter becomes a constitutional obligation of the justices who have been bound by an oath to uphold and maintain the constitution. ${ }^{15}$ Thus, the Supreme Court was seen to have an obligation to maintain the constitution supremacy that determines the constitution as the highest law of the land and maintain the checks and balances system. ${ }^{16}$

By the end of the $19^{\text {th }}$ century, George Jellinek was well known with the idea of reviewing the constitutionality of laws at separate judiciary outside the Supreme Court, ${ }^{17}$ also the authority to hear disputes between citizens and the government concerning constitutional objections raised by citizens for the actions of the state, and accommodated into Constitution of Austria 1920 through the establishment of Verfassungsgerichtshof.

The existence of the Constitutional Court of Indonesia examines their duties to protect the rule of law and adheres as guardians of the constitution, final interpreter of the constitution, protector of human rights, and protector of the constitutional rights. ${ }^{18}$ That role exists under democracy, law, justice and democracy principles. The Constitutional Court authorities regulate in Article 24 C (1) of the 1945 Indonesian Constitution and Article 10 (1) (a)

\footnotetext{
${ }^{14}$ T. Ginsburg, \& Z. Elkins, "Ancillary Powers of Constitutional Courts", Texas Law Review 87, No. 7 (2008):1431-1461, p. 1434.

${ }^{15}$ I.G. Yusa, \& B.Hermanto, "Gagasan Rancangan Undang-undang Lembaga Kepresidenan: Cerminan Penegasan dan Penguatan Sistem Presidensiil Indonesia," Jurnal Legislasi Indonesia 14, No. 3 (2017): 313-324, pp. 315-316.

16 J. Asshiddiqie, "Universalization of Democratic Constitutionalism and the Work of Constitutional Court Today", Constitutional Review 1, No. 2 (2015), doi: 10.31078/consrev121, 1-22, pp. 9-10.

${ }^{17}$ J. L. Marshfield, “The Amendment Effect”, Boston University Law Review 98, No. 1(2018): 57-123, p. 74.

18 A. Desiana, "Analisis Kewenangan Mahkamah Konstitusi dalam Mengeluarkan Putusan yang Bersifat Ultra Petita Berdasarkan Undang-Undang Nomor 24 Tahun 2003”, Majalah Hukum Forum Akademika 25, No. 1 (2014): 42-58, p. 50.
} 
Law of Constitutional Court ${ }^{19}$ that determines the Constitutional Court's authority to adjudicate at the first and final instance on the matter to review on the laws against the Constitution, ${ }^{20}$ to judge an authority disputes of Indonesia's state institutions whose authorities are granted by the Constitution, to decide on the matter of political party dissolution in Indonesia and to judge on general election result dispute. ${ }^{21}$

\section{Ultra Petita's Verdict in the Constitutional Court Procedural Law}

The limitation of the authority of the Constitutional Court to conduct ultra petita or decide more than what was requested has brought academic debate. $^{22}$ On the one hand, there is an opinion that it has closed the Constitutional Court's room to find substantive justice, as has been done by the Constitutional Court. ${ }^{23}$ On the other hand, some argue that it provides legal certainty because the Constitutional Court can be more careful in deciding the petition for constitutionality review. ${ }^{24}$

Provisions in Article 178 (2) and (3) H.I.R. and Article 189 (2) and (3) R.Bg. firmly formulate the prohibition of ultra petita for the judge, ${ }^{25}$ that judges are prohibited from making decisions beyond what is requested. However, according to the characteristics of a case under the Constitutional Court's authority, it cannot be said that prohibition of ultra petita can be applied to justice in Constitutional Court, especially based on the provisions of H.I.R. and R.Bg. ${ }^{26}$

In practice, Decision Number 001-021-022/PUU-I/2003 and Decision Number 006/PUU-IV/2006 justify the decision of ultra petita, especially if the article being tested is the core of provisions' execution. Cancellation of certain articles will only lead to legal uncertainty, so it does not conflict with

19 A. Bedner, "Indonesian Legal Scholarship and Jurisprudence as an Obstacle for Transplanting Legal Institutions," Hague Journal on the Rule of Law 5, No. 2 (2013): 253-273, doi: https://doi.org/10.1017/S1876404512001145, p. 264.

${ }^{20}$ B. Bisariyadi, "A Typical Rulings of the Indonesian Constitutional Court", Hasanuddin Law Review2, No. 2 (2016): 225-240, DOI: http://dx.doi.org/10.20956/halrev.v1i2.306, p. 226.

${ }^{21}$ M. Faqih, "Nilai-nilai Filosofi Putusan Mahkamah Konstitusi yang Final dan Mengikat", Jurnal Konstitusi 7, No. 3 (2010): 97-118, doi: 10.31078/jk\%x, p. 100.

${ }^{22}$ Benny Kabur Harman, Mempertimbangkan Mahkamah Konstitusi: Sejarah Pemikiran dan Pengujian UU terhadap UUD (Jakarta: Kepustakaan Popular Gramedia, 2013), 95-96.

${ }^{23}$ R. Ajie, "Batasan Pilihan Kebijakan Pembentuk Undang-Undang (Open Legal Policy) dalam Pembentukan Peraturan Perundang-Undangan berdasarkan Tafsir Putusan Mahkamah Konstitusi”, Jurnal Legislasi Indonesia 13, No. 2 (2016): 111-120, pp. 115-116.

${ }^{24}$ H. Alrasid, "Hak Menguji dalam Teori dan Praktek" Jurnal Konstitusi 1, No. 1 (2004):68104, p. 96.

${ }^{25}$ Tim Penyusun Buku Hukum Acara Mahkamah Konstitusi, Hukum Acara Mahkamah Konstitusi, Cetakan Pertama, (Jakarta: Kepaniteraan dan Sekretariat Jenderal Mahkamah Konstitusi Republik Indonesia, 2010), 53-54.

${ }^{26}$ Ahmad Syahrizal, Peradilan Konstitusi: Suatu Studi tentang Adjudikasi Konstitusional Sebagai Mekanisme Penyelesaian Sengketa Normatif (Jakarta: Pradnya Paramita, 2006), 4. 
the constitution, especially after Decision Number 48-49/PUU-IX/2011, that ultra petita decision in the context of the Constitutional Court decides a trial case constitutionality is constitutional.

The Constitutional Court has also stated that Article 45A and Article 57 paragraph (2a) of Law Number 8 of 2011 regarding Amendment to Law Number 24 of 2003 regarding the Constitutional Court. Law Number 8 of 2011 is no longer valid, with several considerations namely:

First, the Article 57 paragraph (2a) of Law Number 8 of 2011 is contrary to the purpose of establishing a Constitutional Court to enforce law and justice, especially in the context of enforcing the constitutionality of norms of laws under the Constitution. The objective thing of establishing the Constitutional Court is to improve the law through judicial review. Therefore, constitutional judges are required to explore, follow, and understand the legal values and sense of justice that lives in society to form new laws through the decisions of the Court.

Second, the provision of Article 57 paragraph (2a) of Law Number 8 of 2011 results in obstruction of the Constitutional Court ${ }^{27}$ is to (i) examine the constitutionality of norms; (ii) fill the legal vacuum as a result of the Court's decision stating that a norm is contrary with Basic Law and unbinding. Meanwhile, the process of forming a law takes a long time, so it cannot immediately fill the legal vacuum; (iii) carrying out the obligations of constitutional judges to explore, follow and understand the legal values and sense of justice that lives in society. ${ }^{28}$

Third, the character of procedural law in the Constitutional Court, especially in the case of review is to defend constitutional rights and interests protected by the constitution, as a result of the enactment of a generally accepted law (ergaomnes). Therefore, if the public interest requires, constitutional judges may not be fixed only on the petition.

\section{Study of Constitutional Court Decisions Classified as Ultra Petita Decisions}

The Constitutional Court also affirmed its attitude both through the constitutionality review of the Law Number 20 of 2002 concerning Electricity through the Decision Number 001-021-022/PUU-I/2003 as well as testing of Law Number 27 of 2004 concerning the Truth and Reconciliation Commission through the Decision Number 006/PUU-IV/2006, if the article being tested is the core or determines the law implementation. Cancellation of certain articles will lead to legal uncertainty, so it does not conflict with the

\footnotetext{
${ }^{27}$ Kepaniteraan dan Sekretariat Jenderal Mahkamah Konstitusi Republik Indonesia, "Putusan Ultra Petita Konstitusional", Majalah Konstitusi, Edisi Oktober, No. 57 (2011): 10-16.

${ }^{28}$ S. Abadi, "Ultra Petita dalam Pengujian Undang-Undang oleh Mahkamah Konstitusi", Jurnal Konstitusi 12, No. 3 (2015): 586-603, doi: 10.31078/jk1238, pp. 586-588.
} 
constitution, that the ultra petita decisions in the context of the Constitutional Court decide a constitutionality review case is constitutional.

\section{Decision Number 001-021-022/PUU-I/2003}

In particular, decision Number 001-021-022/PUU-I/2003 affirms that the Constitutional Court has cancelled Law Number 20 of 2002 concerning Electricity as a whole. The Constitutional Court in its legal considerations focuses more on examining Article 16, Article 17 paragraph (3), and Article 68 of Electricity Law which orders the system of separating/solving the electricity business (unbundling system) with different business actors. Still, because the articles are the main content and paradigm that underlies the Electricity Law, so the entire Electricity Law is declared to be binding. ${ }^{29}$ The Court believes that the system conflicts with Article 33 of the 1945 Indonesia Constitution because it is deemed to make the State-Owned Enterprises worse off which will lead to secure electricity supply to all levels of society, both commercial and non-commercial.

\section{Decision Number 007/PUU-III/2005}

The Constitutional Court Decision Number 007/PUU-III/2005 specifically related to the review of Law Number 40 of 2004 concerning the National Social Security System (NSSS). Petitioner requested that Article 5 (1), (3) and (4) and Article 52 of NSSS Law are declared contrary to the Article 34 paragraph (2) of the 1945 Indonesia Constitution and unbinding. ${ }^{30}$ The main focus in this petition is whether the meaning of the state in the phrase "the State develops a social security system ..." rests with the Central Government, Regional Government or both. ${ }^{31}$ Constitutional Court rejected the petition of constitutionality reviewing Article 5 (1) and Article 52 of the Law but stipulated Article 5 (2) of the law contrary with the 1945 Indonesia Constitution and stated this article unbinding, even though the Petitioners did not ask for it in the petition. ${ }^{32}$ In legal considerations relating to ultra petita, Article 5 paragraph (2) which reads, "since the enactment of this law, the existing social security organizing body is declared as the Social Security

29 S. E. Wibowo, "Memahami Makna Pasal 33 Undang-undang Dasar Negara Republik Indonesia Tahun 1945 perihal Penguasaan oleh Negara terhadap Sumber Daya Alam", Jurnal Legislasi Indonesia 12, No. 4 (2015): 419-442, pp. 426-428.

${ }^{30}$ H. Siallagan, "Masalah Putusan Ultra Petita dalam Pengujian Undang-Undang", Mimbar Hukum 22, 1(2010): 71-83, doi: https://doi.org/10.22146/jmh.16209, p. 78-79.

${ }^{31}$ M. A.Zain, A. P.Yurista, \& M. E.Yuniza, "Konsistensi Pengaturan Jaminan Sosial Terhadap Konsep Negara Kesejahteraan Indonesia”, Jurnal Penelitian Hukum Gadjah Mada 1, 2 (2014): 63-76, p. 72-74.

${ }^{32}$ B.Bisariyadi, "Pergulatan Paham Negara Kesejahteraan (Welfare State) dan Negara Regulasi (Regulatory State) dalam Perkara Konstitusional”, Jurnal Hukum Ius Quia Iustum 23, No. 4 (2016): 531-551, DOI: https://doi.org/10.20885/10.20885/iustum.vol23.iss4.art1, p. 544-546. 
Organizing Body according to this law", ${ }^{33}$ the Constitutional Court stated, that despite it is not requested in the petition. Still, this paragraph is a unity that cannot be separated from paragraph (3); therefore if it is maintained, it will even cause multiple interpretations and legal uncertainty.

\section{Decision Number 003/PUU-IV/2006}

Decision Number 003/PUU-IV/2006 specifically concerning Judgment by the Constitutional Court related to Article 2 (1) along with the explanation of Law Number 31 of 1999. The main issue that appears in this decision is the annulment of the provisions on the expansion of the element "nature against material law" as formulated in the Elucidation of Article 2 (1) of this Law. ${ }^{34}$ In the decision, Constitutional Court clearly stated that the petition for judicial review of the word "can" and "trial" as the subject of the petite was rejected. However, the Court determined that the Elucidation of Article 2 paragraph (1) of this Law was considered to have expanded the category of the element "against the law" in the sense of written law (formelewederrechtelijk), but also in the sense of materielewederrechtelijkheid (nature against material law). ${ }^{35}$ Therefore, it contradicts the 28D paragraph (1) of the 1945 Indonesia Constitution. According to the Constitutional Court, the explanation of a law may not contain new norms, because the explanation only includes a description or further elaboration of norms regulated in the body. The recognition of the teachings against the material law in Article 2 paragraph (1) of this Law will also cause legal problems, because what is appropriate and that meets the requirements of morality and a sense of justice that is recognized in society, which varies from region to region, will result in legal uncertainty. This decision does not provide an explanation directly related to why the Constitutional Court conducted ultra petita.

\section{Decision Number 005/PUU-IV/2006}

Decision Number 005/PUU-IV/2006 is a decision on the review of Law Number 22 of 2004 concerning the Judicial Commission and Law Number 4 of 2004 concerning the Judicial Power of the Indonesia Constitution. The main issue raised in the decision is the unclear mechanism

\footnotetext{
${ }^{33}$ E. Elviandri, K. Dimyati, \& A. Absori, "Quo Vadis Negara Kesejahteraan: Meneguhkan Ideologi Welfare State Negara Hukum Kesejahteraan Indonesia", Mimbar Hukum 31, No. 2 (2019): 252-266, doi: https://doi.org/10.22146/jmh.32986, p. 262-263.

34 W. Anjari, "Kedudukan Asas Legalitas Pasca Putusan Mahkamah Konstitusi Nomor 003/PUU-IV/2006 dan 025/PUU-XIV/2016", Jurnal Konstitusi 16, No. 1 (2019): 1-22, doi: https://doi.org/10.31078/jk1611, p. 13.

35 A. Adhari, "Konstitusionalitas Materiele Wederrechtelijk dalam Kebijakan Pemberantasan Tindak Pidana Korupsi: Kajian Putusan Mahkamah Konstitusi Nomor 003/PUUIV/2006”, Jurnal Yudisial 11, No. 2 (2018): 131-150, http://dx.doi.org/10.29123/jy.v11i2.260, p. 133.
} 
of supervising judges in the Judicial Commission Law, thereby causing legal uncertainty. ${ }^{36}$ In this Decree, at least two ultra-petite contents can be found. First, related to the exclusion of Constitutional Court judges' behaviour from the object by the Judicial Commission. Second, related to the eradication of the entire authority of the Judicial Commission in supervising judges. ${ }^{37}$ This happened because the petition of the petitioners was more related to the desire that the supreme judge not included as a party overseen by the Judicial Commission. Still, the Constitutional Court even annulled all the provisions related to the supervision of the Judicial Commission to supervise judges.

Constitutional Court in its legal consideration stated that this exception (Constitutional Court Judge) was based on a systematic understanding and interpretation based on the original intent of the formulation of Article 24B and Article 24C of the 1945 Indonesian Constitution.

Constitutional Court considers "that the implementation of the supervisory function arises from legal uncertainty (rechtsonzekerheid) as a result of the absence of clear norms about the scope of understanding of judges' behaviour and justice technical oversight related to the limits of accountability from a judge behavioural perspective with the independence of a judge in carrying out his judicial duties is in plain view an intervention against the judicial authority in the form of direct or indirect pressures.

\section{Decision Number 006 / PUU-IV / 2006}

Decision Number 006/PUU-IV/2006 specifically cancelled Law Number 27 of 2004 concerning the Truth and Reconciliation Commission as a whole. ${ }^{38}$ In their petition, the Petitioners argue that the existence of Article 1(9), Article 27 and Article 44 of this Law is in contrary with Article 27 (1), 28D (1), and 28I (2) of the 1945 Indonesian Constitution. ${ }^{39}$ According to the Petitioners, norms in Article 27 of Truth and Reconciliation Commission Law have negated guarantees of anti-discrimination, equality before the law and respect for human dignity guaranteed by the Indonesia Constitution.

\footnotetext{
${ }^{36}$ F. E. Siregar, "Indonesia Constitutional Court: Constitutional Interpretation Methodology (2003-2008)", Constitutional Review 1, 1 (2015): 1-27, doi: 10.31078/consrev111, pp. 7-8, 14$16,18-19$.

${ }^{37}$ P. Windrawan, "Putusan Mahkamah Konstitusi tentang Keberadaan Lembaga Negara: Kajian Tiga Putusan Mahkamah Konstitusi: Nomor 005/PUU-IV/2006; Nomor 006/PUU-IV/2006 dan Nomor 030/SKLN-IV/2006", Jurnal Yudisial 7, No. 1 (2014): 88-102, doi:http://dx.doi.org/10.29123/jy.v7i1.95, p. 92-94.

38 M. A. Putra, "Eksistensi Lembaga Negara dalam Penegakan Hak Asasi Manusia di Indonesia", Fiat Justisia: Jurnal Ilmu Hukum 9, No. 3 (2015): 256-292, doi: https://doi.org/10.25041/fiatjustisia.v9no3.600, p. 264-266.

${ }^{39}$ A. Abdurrahman, \& M. Susanto, "Urgensi Pembentukan Undang-Undang Komisi Kebenaran dan Rekonsiliasi di Indonesia dalam Upaya Penuntasan Pelanggaran HAM Berat di Masa Lalu", Padjadjaran Journal of Law 3, No. 3 (2016): 509-530, doi: https://doi.org/10.22304/pjih.v3.n3.a4, p. 517-518.
} 
Moreover, the existence of Article 44 of this Law is considered to eliminate the obligation of the state to prosecute and punish perpetrators.

In this decision, Article 27 of this Law was contrary to the Indonesia Constitution, but this article determined as an operation of the entire Law. The Constitutional Court decided to declare that all of the provisions in this Law are unbinding. ${ }^{40}$ According to the Constitutional Court, determining the existence of amnesty as a condition for the fulfilment of compensation and rehabilitation is a matter that overrides the protection of law and justice guaranteed by the Indonesia Constitution.

\section{Decision Number 012-016-019/PUU-IV/2006}

Decision Number 012-016-019 / PUU-IV / 2006 mandates a message that the existence of court dualism which prosecutes corruption (as formulated in Article 53 of Law Number 30 the Year 2002 regarding Corruption Eradication Commission) is contradictory with the 1945 Indonesia Constitution. Therefore it is necessary to improve the regulation of the corruption court in the Indonesian justice system. ${ }^{41}$

This decision is unique because in its ruling the Constitutional Court postponed the binding enforcement of the decision and provided a time limit of 3 (three) years for the legislators to form the Corruption Court Act, which was then poured into Law Number 46 of 2009 concerning the Court of Acts Criminal Corruption. A request for delay is not requested at all by the applicant. The Constitutional Court postulates that although Article 47 of the Law of the Constitutional Court states that "The Constitutional Court's decision to obtain permanent legal force from the moment it is pronounced in a plenary session is open to the public", the examination of corruption by the Corruption Eradication Commission and the Corruption Court is ongoing, uninterrupted and undisturbed to cause legal uncertainty with the constitution. In this decision, the Constitutional Court considers the need to provide time for a smooth transition process for the formation of new rules and the attitude of statesmanship and wisdom of the judges. These breakthroughs contain the value of expediency and fairness as well as aiming at realizing legal certainty.

\section{Decision Number 5/PUU-V/2007}

\footnotetext{
${ }^{40}$ B. Hermanto, \& M. Aryani, "Gagasan Pengaturan yang Ideal Penyelesaian Yudisial maupun Ekstrayudisial Pelanggaran Hak Asasi Manusia di Indonesia," Jurnal Legislasi Indonesia 15, No. 4 (2019): 369-383, p. 377-378.

${ }^{41}$ H. A. Sasmito, "Ultra Petita Decision of Constitutional Court on Judicial Review (the Perspective of Progressive Law)," Journal of Indonesian Legal Studies 1, No. 1 (2016): 47-68, pp. 56-61. doi: https://doi.org/10.15294/jils.v1i01.16568.
} 
Decision Number 5/PUU-V/2007 specifically the Constitutional Court examined the provisions of Article 56, Article 59, and Article 60 of Law Number 32 the Year 2004 concerning Regional Government which stipulates that candidate pairs can only be proposed/submitted by political parties or join political parties. In other words, it does not provide any opportunities for independent candidate pairs, including the Petitioner.

In this case, the Constitutional Court's Decision exceeds what was petitioned by petitioners who only applied for unconstitutional articles. In addition to declaring that it was contrary to the 1945Indonesian Constitution, articles of this Law only allowed the political parties or a combination political parties and closing the constitutional rights of individual candidates in the elections, namely Article 56 paragraph (2) which reads, "Pair of candidates as referred to in paragraph (1) shall be submitted by a political party or a combination of political parties"; Article 59 paragraph (1) insofar as the phrase "proposed by a political party or a combination of political parties"; Article 59 paragraph (2) insofar as the phrase "referred to in paragraph (1)"; and Article 59 paragraph (3) insofar as the phrase "a political party or a combination of political parties is obligatory", the phrase "to the greatest extent", and the phrase "and subsequently process the intended candidate". ${ }^{42}$ However, the Constitutional Court changed the articles through the ruling, so Article 59 paragraph (1) became "Participants in the election of regional heads and deputy regional heads are pairs of candidates"; Article 59 paragraph (2) becomes "A political party or a combination of political parties may register pairs of candidates if they meet the acquisition requirements of at least $15 \%$ (fifteen percent) of the total number of Regional Council seats or 15\% (fifteen percent) of the accumulation of valid votes in the general election of Regional Council members"; and Article 59 paragraph (3) becomes "opening opportunities for prospective individuals who meet the requirements referred to in Article 58 through democratic and transparent mechanisms".

\section{Decision Number 102/PUU-VII/2009}

Decision Number 102/PUU-VII/2009 regarding to the submission of constitutional review of Article 28 and Article 111 (1) of Law Number 42 the Year 2008 concerning General Elections of President and Vice President regarding the requirements to be able to vote in General Elections President and vice president. The Petitioner argues that they have legal standing to request the constitutionality review of a quo provision because, in the last 2009 General Election of the President and Vice President, the petitioners and many other voters were not listed on the Permanent Voter List. The results of the examination and verification process, the Constitutional Court stated that

\footnotetext{
${ }^{42}$ H. A. Sasmito, "Putusan Ultra Petita Mahkamah Konstitusi dalam Pengujian Undang-undang (Suatu Perspektif Hukum Progresif)", Jurnal Law Reform 6, No. 2 (2011): 55-81, doi: https://doi.org/10.14710/lr.v6i2.12474, p. 61-62.
} 
the article was conditionally constitutional insofar as it meant other than Indonesian citizens registered in the Permanent Voter Register of Indonesian citizens who had not been registered in the Permanent Voter Register could use their voting rights by showing a valid Citizen ID Card a valid passport for Indonesian citizens who are abroad; Indonesian citizens who use Citizen ID Card must be accompanied by a Resident Register or similar name; voting rights for Indonesian citizens who use a valid Resident Identity Card can only be used at the polling place following the address indicated on their Identity Card; Indonesian citizens as mentioned above, before exercising their voting rights, first register with the local Voting Committee Group; as well as Indonesian citizens, who use their voting rights with an Identity Card / Passport carried out one hour before the completion of the voting at the Polling Place in Indonesia and abroad. ${ }^{43}$

This decision is beneficial for all Indonesian people who want to exercise their right to vote, but are constrained by the chaos of the electoral administration system. However, there are several problems in this decision, namely, the inclusion of Constitutional Court decision in the realm of legislators with forming a new norm, which means the Constitutional Court has carried out an ultra petita, if Article 28 and Article 111 (1) of this Law is abolished, there will be a legal vacuum regarding how the criteria for voters who can vote in this President and Vice President Election. Therefore, the Constitutional Court declared conditionally unconstitutional and made new provisions regarding technical administration of voters that could guarantee the constitutional rights of citizens unconstitutional conditionally. ${ }^{44}$ However, national law regulates that constitutional review of whether the norm being tested is contrary or not to the constitution.

\section{Decision Number 138/PUU-VII/2009}

Decision Number 138/PUU-VII/2009 confirms that the Constitutional Court has the authority to examine Government Regulation instead of Law Number 4 of 2009, contrary to the Constitution. Constitutional Court stated that the petitioners' petition could not be accepted because the Petitioner does not have legal standing. Even if this regulation harms the applicant, the Constitutional Court believes that the constitutional loss is unspecific. Constitutional Court also believes that there are no causalities between the losses argued by the petitioners, and there is no guarantee if granting of a quo petition, constitutional impairment as postulated no longer happens.

\footnotetext{
${ }^{43}$ M. B. Ulum, \& D. Al Farizi, "Implementasi dan Implikasi Putusan MK Terhadap Hak Konstitusional Warga Negara Indonesia", Jurnal Konstitusi 6, No. 3 (2009): 83-103, pp. 8889.

${ }^{44}$ A. M. Asrun, "Hak Asasi Manusia dalam Kerangka Negara Hukum: Catatan Perjuangan di Mahkamah Konstitusi," Jurnal Cita Hukum 4, No. 1 (2016): 133-154, doi: 10.15408/jch.v4i1.3200.2016.4.1.133-154, pp. 147-148.
} 
The decision of the Constitutional Court, which stated that the petition was not acceptable was certainly not something that was fairly new and was one of the legal consequences that might have occurred in judicial review. Indonesian constitutional law has set formal requirements that the applicant must have legal standing, in addition to other material conditions. ${ }^{45}$ However, this decision is the landmark decision of the Constitutional Court, because the Constitutional Court stated that it was authorized to examine, try and decide on the Government Regulation in the trial of judicial review especially considering the authority of the Constitutional Court to examine Government Regulations instead of laws not explicitly stated in the Indonesia Constitution, nor the organic laws related to the authority of the Constitutional Court namely Article 24 C (1) of Indonesia Constitution, Article 10 (1) (a) of Constitutional Court Law and Article 12 (1) of Judicial Power Law.

\section{Decision Number 01/PUU-VIII/2010}

Decision Number 01/PUU-VIII/2010 related to the review of Article 1 (1), Article 4 (1), and Article 5 (1) Law Number 3 of 1997 concerning Juvenile Court. The article states that the minimum limit for a child to be held liable for a criminal is at least eight years. ${ }^{46}$ However, in its decision, the Constitutional Court stated that the eight-year phrase in the provision is conditionally unconstitutional unless it is interpreted as twelve years. ${ }^{47}$ In this case, the norm is contrary to the Indonesian Constitution. Therefore the Constitutional Court declared unconstitutional, ${ }^{48}$ but if the Constitutional Court declared that article contradicted and was not binding, then there was a legal vacuum. Eventually, the Constitutional Court conducted the minimum limit for a child to be held accountable for a criminal sentence of twelve years. This provision was implemented and regulated in Law Number 11 of 2012 concerning the Child Criminal Justice System.

\section{Decision Number 28/PUU-XI/2013}

Decision Number 28 / PUU-XI / 2013 relates explicitly to the review of Law Number 17 of 2012 concerning Cooperatives, which is related to Article

\footnotetext{
${ }^{45}$ S. Isra, Y. Yuliandri, F. Amsari, et.al., "Perkembangan Pengujian Perundang-undangan di Mahkamah Konstitusi (Dari Berpikir Hukum Tekstual ke Hukum Progresif)", Hasil Penelitian, Kerjasama Mahkamah Konstitusi Republik Indonesia dengan Pusat Studi Konstitusi (PUSaKO) Fakultas Hukum Universitas Andalas, (2010), pp. 155-176.

${ }^{46}$ M. Suhayati, "Vonis Pidana terhadap Anak Usia di Bawah 12 Tahun", Info Singkat Sekretariat Jenderal Dewan Perwakilan Rakyat Republik Indonesia V, No. 12/II/P3DI/Juni/2013, pp. 2-3.

${ }^{47}$ B. Satriya, "Anak Membutuhkan Penegak Hukum Humanis (Analisis Putusan MK Nomor 1/PUU-VIII/2010)", Jurnal Konstitusi 8, No. 5 (2016): 649-674, doi: 10.31078/jk\%x, pp. 658659.

${ }^{48}$ M. M. Ali, M. R. Hilipito, \& S. Asy’ari, “Tindak Lanjut Putusan Mahkamah Konstitusi yang Bersifat Konstitusional Bersyarat serta Memuat Norma Baru", Jurnal Konstitusi 12, No. 3 (2015): 631-662, doi: 10.31078/jk1238, p. 638.
} 
1 (1), Article 37 (1) (f), Article 50 (1) (a), Article 50 (2) (a) and (e), Article 55 (1), Article 56 (1), Article 57 (2), Article 66 through Article 84 of the Cooperative Law on the Preamble of the Indonesia Constitution, Article 28C (1), Article 28D (2), Article 28H (4), Article 33 (1) and (4) of the 1945 Indonesia Constitution.

In this case, the Constitutional Court considers that the definition of cooperatives as regulated in the Cooperative Law, its philosophy is not following the nature of the composition of the economy as a joint effort and based kinship principle as contained in Article 33 (1) of the 1945 Indonesia Constitution, understanding that it has been elaborated in other articles in the Cooperative Law so that on the one hand it reduces the rights and obligations of members by making supervisory authorities too broad, and material or financial capital that overrides social capital which is precisely a fundamental characteristic of cooperatives based on the Indonesia Constitution. ${ }^{49}$ On the other hand, cooperatives become the same and are not different from Limited Liability Companies, so this has made the cooperative lose its constitutional spirit as an entity of economic actors typical for a nation that has a philosophy of cooperation gosh. ${ }^{50}$

The Constitutional Court in this decision considers that even though the petition is only limited to certain $a$ quo articles, the article contains substantial norm content that is at the "heart" of the Cooperative Law. So, if only those articles are declared unconstitutional and unbinding, then it will make other articles in the Cooperative Law no longer function. The Constitutional Court also ordered to avoid legal vacuum or legal vacuum in the field of cooperatives that could cause uncertainty and injustice, thus enacting Law Number 25 of 1992 concerning Cooperatives.

\section{Decision Number 85/PUU-XI/2013}

Decision Number $85 / \mathrm{PUU}-\mathrm{XI} / 2013$ is a Constitutional Court ruling regarding constitutional review of Law Number 7 of 2004 concerning Water Resources, which is similar types of Constitutional Court decision but with different arguments from the Decision Number 058-059-060-063/PUUII/2004 and Decision Number 008/PUU-III/2005. However, the application for formal and material testing of this Law was rejected by the Constitutional Court, there are important things that can be noted in the ruling is access to water resources as human rights, as well as the resources contained in water, are also needed by humans to meet other needs, such as for agricultural

\footnotetext{
${ }^{49}$ I. A. T. Prakoso, F. Wisnaeni \& A. Diamantina, "Analisis Putusan Mahkamah Konstitusi Nomor 28/PUU-XI/2013 tentang Pengujian Undang-undang Nomor 17 Tahun 2012 tentang Perkoperasian terhadap Undang-undang Dasar Negara Republik Indonesia 1945”, Diponegoro Law Journal 6, No. 1(2017): 1-13, pp. 10-12.

${ }^{50}$ R. P. Nugraha, "Pembaharuan UU Perkoperasian Pasca Putusan Mahkamah Konstitusi Nomor 28/PUU-XI/2013”, Jurnal Legislasi Indonesia 14, No. 1 (2017): 29-38, pp. 34-36.
} 
irrigation, electricity generation, and for industrial purposes, which have an important role in the progress of human life and are also important factors for humans to can live well. ${ }^{51}$

The principal case being filed for the application that is the Water Resources Law contains a monopoly possession over water resources was contrary with state control right principle by the state and used for the greatest extent prosperity of the people (Article 6 (2) and (3), Article 9, Article 26 (7), Article 80, Article 45, and Article 46 of the Water Resources Law). Water Resources Law contains content that positions the use of skewed water for commercial purposes (vide Article 6, Article 7, Article 8, Article 9 and Article 10 of the Water Resources Law); Water Resources Law contains content that triggers horizontal conflicts (vide Article 29 (2), Article 48 (1), and Article 49 (7) of the Water Resources Law); Water Resources Law removes the state's responsibility in meeting water needs (vide Article 9 (1), Article 40 (4) and (7), Article 45 (3) and (4), Article 49 (2), as well as Article 29 (4) and (5) of the Water Resources Law), and the Water Resources Law is a discriminatory law (vide Article 91 and Article 92 of the Law). ${ }^{52}$

In its decision, the Constitutional Court overturned the overall validity of the Water Resources Law because it doesn't match with six basic principles of water resource management restrictions considered in Decision Number 058-059-060-063/PUU-II/2004 and Decision Number 008/PUU-III/2005, as a determinant aspect of the constitutionality of the Water Resources Law. The constitutionality requirement of the Law is that this Law, in its implementation, must guarantee the realization of the constitutional mandate on the state's right to control water. The right of state control over water, which regulates by the constitution to make policies, holds control in carrying out management, regulatory actions, management actions, and supervisory action-in its consideration, concerning management, regulatory measures, management actions, and supervisory actions of the state as referred to the Decision Number 001-021-022/PUU-I/2003 dated December 15, 2004, regarding the review of Electricity Law.

Decision Number 85/PUU-XI/2013, the thing that becomes an important point in the testing of the Water Resources Law is the affirmation of very strict restrictions in water resources management. ${ }^{53}$ The exploitation of water must not disturb, set aside, let alone abolish people's rights to water because the earth, water and other natural resources must be managed by the state, as an

${ }^{51}$ H. Kasim, \& T. Anindyajati, "Perspektif Konstitusional Kedudukan Negara dan Swasta dalam Pengelolaan Sumber Daya Air Menurut UUD 1945", Jurnal Konstitusi 13, No. 2 (2016): 455-479, doi: 10.31078/jk1238, pp. 462-464.

${ }^{52}$ H. Kasim, "Penegasan Peran Negara dalam Pemenuhan Hak Warga Negara atas Air", Jurnal Konstitusi 12, No. 2 (2015): 353-372, doi: 10.31078/jk1228, p. 364.

${ }^{53}$ A. Triningsih, \& O. V. Agustine, "Putusan Mahkamah Konstitusi yang Memuat Keadilan Sosial dalam Pengujian Undang-Undang”, Jurnal Konstitusi 16, No. 4 (2019): 834-860, doi: https://doi.org/10.31078/jk1648, p. 850. 
allotment for human heritage; the second restriction is that the state must fulfil the people's right to water. The consideration states that accesses to water is a separate human right; the third restriction is that the management of water resources must bear in mind the sustainability of life; the fourth restriction is that water as an important branch of production and controls the livelihoods of many lives, and must be controlled by the state as human heritage (vide Article 33 (2) and (3) of the 1945 Indonesia Constitution), then supervision on the water by the water is absolute; and as a continuation of the right to control by the state and because water is something that controls the livelihoods of many people, the top priority given to the operation of water is a State-Owned or Regional-Owned Enterprise. ${ }^{54}$

The state's right to control water is key to this Water Management Law that reflected by the constitution. Constitutional Court also examined that implementation of this Law into six Government Regulation is related to the examination of the Water Resources Law. If the purpose turns out contrary to the interpretation given by the Court, it shows that the relevant law is contrary to the 1945 Indonesia Constitution. However, the Government has established six regulations. Government has to implement the Water Resources Law. According to the Constitutional Court, the six Government Regulations are unmatched with six basic principles of water resource management restrictions.

Constitutional Court decides the Petitioners' petition is related to the key Water Resources Law and is based on the law for the whole. Constitutional Court also states that the Water Resources Law is declared a contrary provision as stipulated in 1945 Indonesia Constitution and unbinding. In order to prevent the occurrence vacancy regulation concerning water resources until awaiting the formation of a new law, Law Number 11 of 1974 concerning Irrigation is reinstated, and in its development, it has been followed up with Law Number 17 of 2019 concerning Water Resources after the issuance of Decision Number 85/PUU-XI/2013.

In this part, there are groups of ultra petita considerations are used, which is used by the constitutional judge and obtained relating to the reason of constitutional judges makes the ultra petita decision, as follows:

The parts of the law (paragraph, article, explanation) that is asked to be tested is the "heart" of the law so that all articles cannot be implemented and shall be declared not legally binding, as cancellation of Electricity Law (Decision Number 001-021-022 / PUU-I / 2003) and cancellation of Truth and Reconciliation Commission Law (Decision Number 006 / PUU-IV / 2006).

The parts of the law (paragraph, article, and explanation) requested is examined with other articles that cannot be separated, so that related article is

\footnotetext{
${ }^{54}$ I. S. Chandranegara, "Ultra Petita dalam Pengujian Undang-undang dan Jalan Mencapai Keadilan Konstitusional”, Jurnal Konstitusi 9, No. 1 (2012): 27-48, pp. 43-44. doi: $10.31078 / \mathrm{jk} \% \mathrm{x}, \mathrm{p}$.
} 
finally declared as having no legal force. Included in this category of consideration is a review of the National Social Security System Law (Decision Number 007 / PUU-III / 2005), also the Judicial Commission Law (Decision Number 005 / PUU-IV / 2006) it also seems to lead to this consideration, even though the Constitutional Court does not explicitly describe it.

A postponement of decision binding is made while waiting for the establishment of new rules of change. In this case, the reason for the benefit overcomes legal certainty, even though it is related to the issuance of a court judge, the ultimate goal is also to create legal certainty. Included in this category is the decision to cancel the legal basis of the Corruption Court (Decision Number 012-016-019 / PUU-IV / 2006).

Legal consideration of the Constitutional Court in the case of ultra petita is only related to legal considerations on the subject matter of the petition, and it is not infrequently appeared suddenly. In this category, the Constitutional Court authority is to examine the law against the 1945 Indonesia Constitution, so it is not the articles and verses. As long as the relevant laws are tested, there is no ultra petita reflected in cases of cancellation of material unlawful nature in the Anti-Corruption Act (Decision Number 003 / PUU-IV / 2006 and Decision Number 005 / PUU-IV / 2006 which cuts the Judicial Commission Authority, as long as it is related to the issuance of Constitutional Court judges from party supervised by the Judicial Commission).

\section{The truth of Law and Limitation of Ultra Petita into Constitutional Court Decisions: Philosophical, Theoretical and Legal Dogmatic Perspectives}

The justification for the ultra petita ruling in the Constitutional Court's ruling in a philosophical perspective is the inclusion of a subsidiary petition that reads: "If the court has a different opinion, request a ruling as fair as possible (ex aequo et Bono)." ${ }^{55}$ In the preamble, it is stated that, a principle of law and justice that is universally adopted states that "no one may be benefited by deviations and violations of his own doing and no one may be harmed by irregularities and violations committed by others" (Nemocommodumcaperepotest de injuriasuapropria). The court must not allow the rules of procedural justice to enclose and override substantive justice. Article 24 (1) of the 1945 Indonesia Constitution and also taking into account the Article 28D (1) of the 1945 Indonesia Constitution, which is set forth again in Article 45 (1) of Law Number 24 of 2003 that judicially must

\footnotetext{
55 A. Rubaie, N. Nurjaya, M. Ridwan, \& I. Istislam, "Putusan Ultra Petita Mahkamah Konstitusi”, Jurnal Konstitusi 11, No. 1 (2014): 85-106, doi: 10.31078/jk\%x, p. 92.
} 
adhere to the principle of justice equally, principle of legal certainty, and principle of benefits. ${ }^{56}$

Based on the theoretical perspective, ultra petita ruling in the Constitutional Court's Decision was merely a fulfilled sense of community justice, usefulness, and legal certainty. Theoretically, the principle is applied that the court must not reject a case because the law does not or does not yet regulate. Judges shall explore, discover and follow the values of law that live in society. This principle is stated in Article 5 (1) of Judicial Power Law.

Based on the dogmatic legal perspective, the ultra petita decision or the juridical basis of the authority of judicial power in Indonesia, it is constitutionally regulated in the provisions of Article 24 (1) of the Indonesia Constitution as an independent power, to uphold law and justice. In the context of exercising judicial power, the Constitutional Court in administering justice also aims not only to enforce the law but also to enforce substantive justice rather than procedural justice, based on the law that is not always related to formal-procedural provisions. Besides, the purpose and function of the Constitutional Court are to protect human rights, as stipulated in article 28D (1) of the 1945 Indonesian Constitution and the provisions of Article 45 (1) of the Constitutional Court Law. On the other hand, some limits must be considered by the Constitutional Court to decide on constitutionality with the ultra petita decision, which is as follows:

\section{a. The Principles of the State of Law}

In the context of the issuance, ultra petita decision by the Constitutional Court cannot be separated or separated from the principles of the rule of law that are universally applicable, among others, legality principle, legal certainty principle, equality before the law, limitations on the power based on the constitution, and the principle of justice that free and impartial. In principle, every act of state administrators, including judicial institutions, in this case, the Constitutional Court decides more than what is requested by the applicant, must be based on rules and procedures established by law (rule and procedure).

\section{b. The principle of an independent, free and impartial judiciary}

In the context of making decisions of the Constitutional Court which is ultra petita, it is also limited by the principles of a free and impartial tribunal, as stipulated in Article 24 (1) of the Indonesia Constitution and the Constitutional Court Regulation Number 09/PMK/2006 concerning the Imposition of the Code of Ethics and Behavior of Constitutional Justices by

\footnotetext{
${ }^{56}$ I. Perwira, "Refleksi Fenomena Judicialization of Politics pada Politik Hukum Pembentukan Mahkamah Konstitusi dan Putusan Mahkamah Konstitusi", Jurnal Konstitusi 13, No. 1 (2016): 25-47, doi: 10.31078/jk1312, p. 38.
} 
referring to the Bangalore Principles of Judicial Conduct $2002,{ }^{57}$ adjusted to the legal and judicial system Indonesia and the ethics of national life.

The Bangalore Principles which establish the principles of independence, impartiality, integrity, propriety and equality, equality, competence and diligence, and values live in Indonesian society, namely the principles of wisdom and wisdom as a code of ethics for constitutional judges and their application, used as a reference and benchmark in assessing the behaviour of constitutional judges, to promote honesty, trustworthiness, example, chivalry, sportsmanship, discipline, hard work, independence, responsibility, honour, and dignity as a constitutional judge.

\section{c. General Principles of Good State Administration}

The inclusion of general principles of good governance as a limitation on the use of governmental authority is motivated by the inability of the law to follow the development of the legal needs of the community. The fulfilment of legal needs based on the principles of good state administration is needed to limit the use of free authority because of the limitations of positive law in regulating existing problems, shall immediately resolve to realize legal certainty and community justice.

Constitutional Court's authority to issue the ultra petita decisions, can be used as a basic reference limitation into the authority of the Constitutional Court as judicial institutions. The limitation is to prevent abuse of authority, and this limitation is certainly under the rule of law, that every use of authority must always be determined and its legal basis discovered. Also, its validity can examine the law by the Constitutional Court. ${ }^{58}$

Besides philosophical-juridical, this authority is often referred to as an ultra petita decision that can be justified. Still, the limitation as a negative legislator must be maintained so as not to shift and exceed the authority of parliament. Philosophically, the efforts of the Constitutional Court in its decision to find justice that is substantial rather than merely finding procedural justice. Based on these formal and philosophical considerations, the Constitutional Court's decision that uses the principle of ultra petita must be carried out in a limited manner and uses the principle of prudence.

\section{Conclusion}

First, the limitation Constitutional Court's authority to examine ultra petita decisions or decide more than what was petitioned has invited debate. On the one hand, there is an opinion that it has closed the space of the

\footnotetext{
${ }^{57}$ Jimly Asshiddiqie, Perkembangan dan Konsolidasi Lembaga Negara di Indonesia, (Jakarta: Sinar Grafika, 2010), 106-107.

${ }^{58}$ Z. W. P. Ayu \& H. Adam, "Putusan Ultra Petita Mahkamah Konstitusi dalam Perkara Pengujian Konstitusionalitas Undang-Undang”, Yuridika 29, No. 2 (2014): 168-190, pp. 169170.
} 
Constitutional Court to find substantive justice. On the other hand, some argue that it provides legal certainty. This condition shifting the Constitutional Court can be more careful in examining the petition for constitutionality review. In practice, the Constitutional Court through several Constitutional Court's Decision justifies the decision of ultra petita especially if the article is the core or determining the operation of the provisions of the law, the cancellation of certain articles leads to legal uncertainty. The ultra petita decision in the context of the Constitutional Court decides a constitutionality review case is constitutional, stating that Article 45A and Article 57 (2a) of Constitutional Court Law is no longer valid.

Second, there is a justification for the ultra petita decision from a philosophical, theoretical and dogmatic perspective, with an emphasis on the Constitutional Court role in the context of enforcing substantive justice rather than procedural justice, with the reason that justice based on law is not always legal related to formal-procedural provisions. The justification of the ultra petita decision of the Constitutional Court must be given restrictions that are associated with the context of the principles of the rule of law, the principle of an independent, free, and impartial judiciary as well as the general principles of good state administration.

\section{References}

Abadi, S. "Ultra Petita dalam Pengujian Undang-Undang oleh Mahkamah Konstitusi." Jurnal Konstitusi 12, No. 3 (2015): 586-603, $10.31078 / \mathrm{jk} 1238$.

Abdurrahman, A., \& Susanto, M. "Urgensi Pembentukan Undang-Undang Komisi Kebenaran dan Rekonsiliasi di Indonesia dalam Upaya Penuntasan Pelanggaran HAM Berat di Masa Lalu." Padjadjaran Journal of Law 3, No. 3 (2016): 509-530, https://doi.org/10.22304/pjih.v3.n3.a4.

Adhari, A. "Konstitusionalitas Materiele Wederrechtelijk dalam Kebijakan Pemberantasan Tindak Pidana Korupsi: Kajian Putusan Mahkamah Konstitusi Nomor 003/PUU-IV/2006.” JurnalYudisial 11, No. 2(2018): 131-150, http://dx.doi.org/10.29123/jy.v11i2.260.

Ajie, R. "Batasan Pilihan Kebijakan Pembentuk Undang-Undang (Open Legal Policy) dalam Pembentukan Peraturan Perundang-Undangan berdasarkan Tafsir Putusan Mahkamah Konstitusi."Jurnal Legislasi Indonesia 13, No. 2 (2016): 111-120.

Ali, M. M., Hilipito, M. R., \& Asy’ari, S. “Tindak Lanjut Putusan Mahkamah Konstitusi yang Bersifat Konstitusional Bersyarat serta Memuat Norma Baru." Jurnal Konstitusi 12, No. 3 (2015): 631-662, doi: 10.31078/jk1238. 
Alrasid, H. "Hak Menguji dalam Teori dan Praktek."Jurnal Konstitusi 1, 1 (2004): 68-104.

Anjari, W. "Kedudukan Asas Legalitas Pasca Putusan Mahkamah Konstitusi Nomor 003/PUU-IV/2006 dan 025/PUU-XIV/2016." Jurnal Konstitusi 16, No. 1 (2019): 1-22, https://doi.org/10.31078/jk1611.

Aryani, N. M. \& Hermanto, B. "Gagasan Pengaturan yang Ideal Penyelesaian Yudisial maupun Ekstra Yudisial Pelanggaran Hak Asasi Manusia di Indonesia." Jurnal Legislasi Indonesia 15, 4 (2018): 369-383.

Aryani, N. M. \& Hermanto, B. "Gagasan Perluasan Lembaga Negara Sebagai Pihak Pemohon dalam Sengketa Kewenangan antar Lembaga Negara di Mahkamah Konstitusi Republik Indonesia." Jurnal Legislasi Indonesia 16, No. 2 (2019):173-189.

Asrun, A. M. "Hak Asasi Manusia dalam Kerangka Negara Hukum: Catatan Perjuangan di Mahkamah Konstitusi." Jurnal Cita Hukum 4, No. 1 (2016): 133-154, 10.15408/jch.v4i1.3200.2016.4.1.133-154.

Asshiddiqie, J. "Universalization of Democratic Constitutionalism and the Work of Constitutional Court Today." Constitutional Review 1, 2(2015): 1-22, doi: 10.31078/consrev121.

Asshiddiqie, Jimly Perkembangandan Konsolidasi Lembaga Negara di Indonesia. Jakarta: Sinar Grafika, 2010.

Ayu, Z. W. P. \& Adam, H. "Putusan Ultra Petita Mahkamah Konstitusi dalam Perkara Pengujian Konstitusionalitas Undang-Undang." Yuridika 29, No. 2 (2014): 168-190.

Bedner, A. "Indonesian Legal Scholarship and Jurisprudence as an Obstacle for Transplanting Legal Institutions." Hague Journal on the Rule of Law 5, No. 2 (2013): 253-273, https://doi.org/10.1017/S1876404512001145.

Bisariyadi, B. "A Typical Rulings of the Indonesian Constitutional Court."Hasanuddin Law Review 2, No. 2 (2016): 225240,http://dx.doi.org/10.20956/halrev.v1i2.306.

Bisariyadi, B. "Pergulatan Paham Negara Kesejahteraan (Welfare State) dan Negara Regulasi (Regulatory State) dalam Perkara Konstitusional." Jurnal Hukum Ius Quia Iustum 23, No. 4 (2016): 531-551, https://doi.org/10.20885/10.20885/iustum.vol23.iss4.art1.

Chandranegara, I.S. "Ultra petita dalam Pengujian Undang-undang dan Jalan Mencapai Keadilan Konstitusional." Jurnal Konstitusi 9, No. 1 (2012): 27-48, doi: $10.31078 / \mathrm{jk} \% \mathrm{x}$.

Choudhury, N. "Revisiting Critical Legal Pluralism: Normative Contestations in the Afghan Courtroom."Asian Journal of Law and Society 4, 1(2017): 229-255, doi: 10.1017/als.2017.2.

Desiana, A. "Analisis Kewenangan Mahkamah Konstitusi dalam Mengeluarkan Putusan yang Bersifat Ultra petita Berdasarkan 
Undang-Undang Nomor 24 Tahun 2003."Majalah Hukum Forum Akademika 25, 1(2014):42-58.

Eddyono, L.W. "Independence of the Indonesian Constitutional Court in Norms and Practices."Constitutional Review 3, 1(2017):71-97, doi: https://doi.org/10.31078/consrev314.

Elviandri, E, Dimyati, K., \&Absori, A. "Quo Vadis Negara Kesejahteraan: Meneguhkan Ideologi Welfare State Negara Hukum Kesejahteraan Indonesia." Mimbar Hukum 31, 2 (2019): 252-266, https://doi.org/10.22146/jmh.32986.

Faqih, M. "Nilai-nilai Filosofi Putusan Mahkamah Konstitusi yang Final dan Mengikat." Jurnal Konstitusi 7, 3 (2010): 97-118, doi: $10.31078 / \mathrm{jk} \% \mathrm{x}$.

Ginsburg, T. \& Elkins, Z. "Ancillary Powers of Constitutional Courts." Texas Law Review 87, No. 7 (2008): 1431-1461.

Harman, Benny Kabur. Mempertimbangkan Mahkamah Konstitusi: Sejarah Pemikirandan Pengujian UU terhadap UUD. Jakarta: Kepustakaan Popular Gramedia, 2013.

I Gede Yusa and Bagus Hermanto, et.al. Hukum Tata Negara Pasca Perubahan UUD NRI 1945, Cetakan Pertama. Malang: Setara Press, 2016.

Isra, S., Yuliandri, Y., Amsari, F., et.al. "Perkembangan Pengujian Perundang-undangan di Mahkamah Konstitusi (Dari Berpikir Hukum Tekstual ke Hukum Progresif)."Hasil Penelitian, Kerjasama Mahkamah Konstitusi Republik Indonesia dengan Pusat Studi Konstitusi (PUSaKO) Fakultas Hukum Universitas Andalas, (2010).

Kasim, H. "Penegasan Peran Negara dalam Pemenuhan Hak Warga Negara atas Air." Jurnal Konstitusi 12, No. 2 (2015): 353-372, doi: 10.31078/jk1228.

Kasim, H., \& Anindyajati, T. "Perspektif Konstitusional Kedudukan Negara dan Swasta dalam Pengelolaan Sumber Daya Air Menurut UUD 1945." Jurnal Konstitusi 13, 2 (2016): 455-479, $\quad$ doi: $10.31078 / \mathrm{jk} 1238$.

Kepaniteraan dan Sekretariat Jenderal Mahkamah Konstitusi Republik Indonesia. "Putusan Ultra petita Konstitusional." Majalah Konstitusi, Edisi Oktober, No. 57(2011).

Marshfield, J. L.“The Amendment Effect."Boston University Law Review 98, No. 1 (2018):57-123.

Mietzner, M. "Political Conflict Resolution and Democratic Consolidation in Indonesia: The Role of the Constitutional Court."Journal of East Asian Studies 10, No. 3 (2010): 397-424, https://doi.org/10.1017/s1598240800003672. 
Nardi, D.J. "Can NGOs Change the Constitution? Civil Society and the Indonesian Constitutional Court."Contemporary Southeast Asia 40, No. 2 (2018): 247-278, doi: 10.135.CSA.247-278.

Nugraha, R. P. "Pembaharuan UU Perkoperasian Pasca Putusan Mahkamah Konstitusi Nomor 28/PUU-XI/2013." Jurnal Legislasi Indonesia 14, No. 1 (2017): 29-38.

Omara, A. "The Indonesian Constitutional Court and the Democratic Institutions in Judicial Review."Constitutional Review 3, No. 2 (2017): 189-207, doi: 10.31078/consrev323.

Perwira, I. "Refleksi Fenomena Judicialization of Politics pada Politik Hukum Pembentukan Mahkamah Konstitusi dan Putusan Mahkamah Konstitusi." Jurnal Konstitusi 13, No. 1 (2016): 25-47, doi: $10.31078 / \mathrm{jk} 1312$.

Prakoso, I.A.T., Wisnaeni, F. \& Diamantina, A. "Analisis Putusan Mahkamah Konstitusi Nomor 28/PUU-XI/2013 tentang Pengujian Undangundang Nomor 17 Tahun 2012 tentang Perkoperasian terhadap Undang-undang Dasar Negara Republik Indonesia 1945."Diponegoro Law Journal 6, No. 1 (2017): 1-13.

Putra, M. A. "Eksistensi Lembaga Negara dalam Penegakan Hak Asasi Manusia di Indonesia." Fiat Justisia: Jurnal Ilmu Hukum 9, 3 (2015): 256-292, https://doi.org/10.25041/fiatjustisia.v9no3.600.

Rubaie, A., Nurjaya, N., Ridwan, M. \&Istislam, I. "Putusan Ultra Petita Mahkamah Konstitusi."Jurnal Konstitusi 11, No. 1 (2014): 85-106, doi: $10.31078 / \mathrm{jk} \% \mathrm{x}$.

Safaat, M.A., Widiarto, A.E. \& Suroso, F.L. "Pola Penafsiran Konstitusi dalam Putusan Mahkamah Konstitusi Periode 2003-2008 dan 20092013."Jurnal Konstitusi 14, No. 2 (2017): 234-261, doi: $10.31078 / \mathrm{jk} 1421$.

Safta, M. "Developments in the Constitutional Review: Constitutional Court between the Status of Negative Legislator and the Status of Positive Co-Legislator." Perspective of Business Law Journal 1, No. 1 (2012):1-20.

Sasmito, H. A. "Putusan Ultra Petita Mahkamah Konstitusi dalam Pengujian Undang-undang (Suatu Perspektif Hukum Progresif)." Jurnal Law Reform 6, 2 (2011): 55-81, https://doi.org/10.14710/lr.v6i2.12474.

Sasmito, H.A. "Ultra Petita Decision of Constitutional Court on Judicial Review (the Perspective of Progressive Law)."Journal of Indonesian Legal Studies 1, No. 1 (2016): 47-68, https://doi.org/10.15294/jils.v1i01.16568.

Satriya, B. "Anak Membutuhkan Penegak Hukum Humanis (Analisis Putusan MK Nomor 1/PUU-VIII/2010)." Jurnal Konstitusi 8, 5 (2016): 649674, doi: $10.31078 / \mathrm{jk} \% \mathrm{x}$. 
Shapiro, M."Role Constitutional Court and Problem in Field Constitutional Court.”Indiana Journal of Global Legal Studies 20, No. 1 (2013):253277.

Siallagan, H. "Masalah Putusan Ultra petita dalam Pengujian Undangundang."Mimbar Hukum 22, No. 1 (2010): 71-83, https://doi.org/10.22146/jmh.16209.

Siregar, F.E. "Indonesia Constitutional Court: Constitutional Interpretation Methodology (2003-2008), Constitutional Review 1, No. 1(2015): 127, doi: $10.31078 /$ consrev111.

Sonata, D. L. "Metode Penelitian Hukum Normatif dan Empiris: Karakteristik Khas dari Metode Meneliti Hukum." Fiat Justisia: Jurnal Ilmu Hukum $\quad 8, \quad$ No. 11 (2014): DOI: https://doi.org/10.25041/fiatjustisia.v8no1.283.

Suhayati, M. "Vonis Pidana terhadap Anak Usia di Bawah 12 Tahun." Info Singkat Sekretariat Jenderal Dewan Perwakilan Rakyat Republik Indonesia V, No. 12/II/P3DI/Juni/2013, (2013): 1-4.

Syahrizal, Ahmad.Peradilan Konstitusi: Suatu Studi tentang Adjudikasi Konstitusional Sebagai Mekanisme Penyelesaian Sengketa Normatif. Jakarta: Pradnya Paramita, 2006.

The Constitutional Court of Indonesia. Model dan Implementasi Putusan Mahkamah Konstitusi dalam Pengujian Undang-Undang. Jakarta: Registrar's Office and Secretariat General of the Constitutional Court of the Republic of Indonesia, 2013.

Tim Penyusun Buku Hukum Acara Mahkamah Konstitusi. Hukum Acara Mahkamah Konstitusi. Jakarta: Kepaniteraan dan Sekretariat Jenderal Mahkamah Konstitusi Republik Indonesia, 2010.

Triningsih, A., \& Agustine, O. V. "Putusan Mahkamah Konstitusi yang Memuat Keadilan Sosial dalam Pengujian Undang-Undang." Jurnal Konstitusi 16, No. 4 (2019): $834-860$, https://doi.org/10.31078/jk1648.

Ulum, M. B., \& Al Farizi, D. "Implementasi dan Implikasi Putusan MK Terhadap Hak Konstitusional Warga Negara Indonesia." Jurnal Konstitusi 6, No. 3 (2009): 83-103.

Wibowo, S.E. "Memahami Makna Pasal 33 Undang-undang Dasar Negara Republik Indonesia Tahun 1945 perihal Penguasaan oleh Negara terhadap Sumber Daya Alam."Jurnal Legislasi Indonesia 12, No. 4 (2015): 419-442.

Wijayanti, W. "Eksistensi Undang-undang sebagai Produk Hukum dalam Pemenuhan Keadilan bagi Rakyat (Analisis Putusan Mahkamah Konstitusi Nomor 50/PUU-X/2012)."Jurnal Konstitusi 10, 1 (2013): 179-204, doi: https://doi.org/10.31078/jk\%25x.

Windrawan, P. "Putusan Mahkamah Konstitusi tentang Keberadaan Lembaga Negara: Kajian Tiga Putusan Mahkamah Konstitusi: Nomor 
005/PUU-IV/2006; Nomor 006/PUU-IV/2006 dan Nomor 030/SKLN-IV/2006.”Jurnal Yudisial 7, No. 1 (2014): 88-102, http://dx.doi.org/10.29123/jy.v7i1.95.

Yusa, I.G. \& Hermanto, B. "Gagasan Rancangan Undang-undang Lembaga Kepresidenan: Cerminan Penegasan dan Penguatan Sistem Presidensiil Indonesia." Jurnal Legislasi Indonesia 14, No. 3 (2017): 313-324.

Zain, M. A., Yurista, A. P., \& Yuniza, M. E. "Konsistensi Pengaturan Jaminan Sosial Terhadap Konsep Negara Kesejahteraan Indonesia." Jurnal Penelitian Hukum Gadjah Mada 1, No. 2 (2014): 63-76. 
